\title{
A INTRODUÇÃO DE ESCRAVOS NOVOS NO LITORAL PARANAENSE.
}

\author{
CECILIA MARIA WESTPHALEN \\ Do Instituto de Ciências Humanas, da Universidade \\ Federal do Paraná. \\ 0. - O PROBLEMA.
}

Autores nacionais e estrangeiros repetidas vêzes têm mencionado, na história da extinção do tráfico negreiro para o Brasil, e mesmo enfàticamente, $o$ incidente do Cormorant, havido na baía de Paranaguá, em 1850 .

O presente trabalho objetiva conhecer até que ponto êsse incidente constituiu um fato ocasional, isolado, ou se, ao contrário, encontra-se ligado à prática da introdução de africanos na costa sul, sendo um dos muitos pontos de uma série de evidências que marcam, sobretudo de 1831 a 1851, o litoral de Paranaguá, como receptor de escravos novos.

\section{1. - INTRODUÇÃO.}

Referências têm sido feitas à prática, em grande escala, de contrabando, no século XVIII, pelo pôrto de Paranaguá (1). Entretanto, se, de fato, piratas, corsários e contrabandistas aparecem algumas vêzes na história do pôrto, a sua presença não teve maior importância e significação, salvo em alguns momentos de luta política e de introdução de escravos novos no litoral paranaense, mas já em pleno século XIX.

(1). - Ver: Muret, La préponderance anglaise, p. 400. Mousnier, Le XVIIIe siécle, p. 306. Mauro, L'expansion europeènne, p. 211. 
A suspeita de desembarque de escravos contrabandeados, no pôrto de Paranaguá, data, porém, do primeiro quartel do século XVIII. O Capitão-General de São Paulo, em 1726, tomava disposições no sentido de que o Capitão-Mor da Vila portuária, examinasse tôdas as embarcações ali chegadas, a fim de evitar descaminhos da Fazenda Real. Mas, era o próprio Govêrno da Metrópole que declarava em Carta Régia, face às suspeitas do Capitão-General, que a Paranaguá apenas se dirigiam embarcações em busca de farinhas e peixes, e que o seu negócio não era o de escravos (2).

Sòmente em 1797, volta-se a falar em Paranaguá, como desembarcadouro de escravos negros, quando Francisco de Lacerda e Almeida denunciando à Rainha, as irregularidades do Governador de Moçambique, acusado de favorecer aos franceses, e mesmo aos inglêses, a exportação de escravos e o contrabando, indicava, entre outros, o pôrto de Paranaguá, como ponto de recepção de escravos contrabandeados, no Brasil (3).

Colocado em causa pràticamente a partir da vinda da Família Real ao Brasil foi, contudo, sòmente proibido o tráfico de escravos, pela Regência Trina Permanente, conforme a Lei de 7 de novembro de 1831, regulamentada pelo Decreto de 12 de abril de 1832, a qual declarava livres os escravos desembarcados no Império, punia severamente os seus importadores, e obrigava a reexportação dos negros introduzidos para os portos africanos.

Redobrada a vigilância imperial, e sobretudo a inglêsa, aos grandes portos brasileiros de desembarque habitual de escravos novos, recorreram os traficantes aos navios de baixa tonelagem para a frequiência aos pequenos portos e embarcadouros, quer para a introdução, como para a localização de depósitos de preparação de negros ladinos que iludissem as autoridades.

O pôrto de Paranaguá surge, nessa conjuntura, como ponto de negócios referentes ao tráfico ilícito de escravos novos, desembarcados no litoral da Província de São Paulo.

\section{2. - EVIDENCIAS DO DESEMBARQUE DE AFRICANOS NO LITORAL PARANAENSE.}

Assim, já em setembro de 1833, tanto o Juiz da Paz da Vila de Cananéia, como o Juiz de Direito da $6 \mathrm{a}$. Comarca, comunicavam às

(2) - - Carta Régia de 12 de outubro de 1726. Boletim do Arquivo Municipal de Curitiba, v. 13, p. 49.

(3). - Carta escrita do Rio de Janeiro, em 10 de junho de 1797. Publicada por Fonseca. R. I. H. G. R., v. 192, p. 29-30. 
autoridades das vilas paranaenses o desembarque na costa de Cananéia, ou de Paranaguá, de negros africanos que teriam tomado o destino desta Comarca (4).

Tal participação foi encaminhada, pelas autoridades de Paranaguá, com pedido de informações, a todos os distritos, a fim de averiguar-se, não apenas o desembarque, mas o destino dos negros e, sobretudo, quem teria sido o responsável pela sua introdução (5).

Entretanto, apenas o Juiz de Paz do $2^{\circ}$ Distrito, de Guaraqueçaba, respondia afirmativamente, comunicando que já se encontrava, aliás, em diligências, por constar-lhe que havia desembarcado na barra de Cananéia, uma porção de escravos que seguiram pela praia, da parte do mar grosso, e haviam embarcado no pontal do Superaguí, em canoas de voga, com destino a Antonina (6). Tôdas as demais autoridades ouvidas, negaram qualquer conhecimento da matéria (7).

Considerando, porém, a participação feita pelo Juiz de Paz de Cananéia e pelo Juiz de Direito da 6a. Comarca, e a informação dada pelo Juiz de Paz de Guaraqueçaba, foi aberto, ainda em setembro, em Paranaguá, auto sumário de inquirição de testemunhas para o conhecimento de quem fôra o introdutor de escravos novos, e se os mesmos estavam no têrmo, a fim de que fôsse punido o responsável, na conformidade da lei de 1831 (8). As testemunhas ouvidas, contudo, declararam que nada haviam visto e nada sabiam a respeito de africanos desembarcados recentemente em Cananéia (9). Apenas uma delas, ouvira dizer que junto à ilha do Abrigo de Cananéia, encontrava-se uma embarcação com africanos.

A entrada, logo a seguir, -no pôrto de Paranaguá, do bergantim português Feliz Independente (10), vindo de Loanda, fêz recair sô-

(4). - Ofícios do Juiz de Paz da Vila de Cananéia, de 10 de setembro de 1833 e do Juiz de Direito da ta. Comarca, de 19 de setembro de 1833. D.A.E.S.P. - Ofícios diversos - Paranaguá. Caixa $\mathrm{n}^{\circ} 341$.

(5). - Ofícios do Juiz de $\mathrm{Paz}$ de Paranaguá aos Juizes de tôdas as vilas paranaenses. Ibidem.

(6). - Ofício do Juiz de Paz do $2^{\circ}$ Distrito de Paranaguá (Guaraqueçaba), de 26 de setembro de 1833. Ibidem.

(7). - Ofícios do Juiz de Paz de Antonina, do Juiz Municipal de Antonina, e do Juiz de Paz de Guaratuba. Ibidem.

(8). - Auto do Processo de Inquirição de Testemunhas feito pelo Juiz de Paz de Paranaguá, em 28 de setembro de 1833.

(9). - As 5 testemunbas ouvidas negaram ter conhecimento, afirmando que nada sabiam. A leitura do Processo, no entanto, conduz à convicção do desembarque.

(10) . - Embarcação de 250 toneladas, de propriedade de Cândido Francisco da Silva, de Loanda. Realizou a viagem em direitura, levando 35 dias, de Loanda a Paranaguá. Ibidem. 
bre ela, a suspeita de que fôra a embarcação que estivera em Cananéia.

Assim, pelo Juiz de Paz de Paranaguá foi procedida a sua vistoria, nada, porém, sendo encontrado que confirmasse os rumores. Os seus papéis estavam em ordem e, não havia a bordo, utensílios do tráfico (11).

E' certo, entretanto, que o bergantim vindo em direitura da costa da África não trouxera carga, devendo, com moeda sonante, adquirir gêneros da praça, em Paranaguá, a fim de seguir viagem a Buenos Aires (12).

A Presidência da Província continua, porém, a exigir providências acêrca daquêle desembarque e das suspeitas sôbre o Feliz Independente. Nova visita foi realizada ao bergantim, e nada foi encontrado (13). Da mesma maneira, nova inquirição de testemunhas vindas de Cananéia, acareadas com o mestre da embarcação, também não produziu resultados. Tôdas ouviram dizer da embarcação em Cananéia, mas não a reconheciam no Feliz Independente, e nem ao seu mestre (14) . Em conclusão, o Juiz de Paz comunica ao Presidente da Província que, apesar de tôdas as suas diligências, não descobrira qual a embarcação e, muito menos, quais os indivíduos que haviam introduzido escravos (15).

Mas, a dúvida persiste. Ante a pressão das autoridades provinciais, a Câmara Municipal de Paranaguá ordena nova inquirição de

(11). - Aıtuação de um mandado para visita e vistoria do bergantim Feliz Independente, pelo Juiz de Paz de Paranaguá, em 7 de outubro de 1833. Ibidem.

(12). - Carta de instrucōes dadas pelo proprietário do bergantim ao seu consignatário Amaro José dos Santos Barbosa, constitui peça valiosa para a compreensão de como trarscorria o negócio. O consignatário, saindo de Loanda, em direção à Paranaguá, nesta Vila deveria comprar, com 4.000 moedas de ouro que trazia, madeiras, aguardente e arroz. Em seguida dirigir-se-ía a Buenos Aires, onde venderia os gêneros paranaenses e compraria mulas. De Buenos Aires seguiria para - Cabo da BoaEsperança, onde venderia as mulas e compraria os melhores gêneros da praça com aceitação em Goa. Nesta última, vendidos os gêneros trazidos de Boa Esperança, compraria fazendas, chá, couros curtidos, pólvora e canela que levaria a Loanda. Neste gire, tudo leva a crêr que as 4.000 moedas de 960 réis, eram recebidas, no litoral paranaense, em troca dos africanos.

(13). - Autuação de um mandado para visita e vistoria do bergantim $F_{c} l i z$ Independente, pelo Juiz de $\mathrm{Paz}$ de Paranaguá, em 16 de novembro de 1833. Ibidem.

(14). - Auto de Perguntas feitas pelo Juiz de Paz de Paranaguá, às testemunhas vindas de Cananéia e ao mestre do Feliz Independente, em 20 de novembro de 1833. Ibidem.

(15). - Carta do Juiz de Paz, João Machado Lima, ao Presidente da Província, em 24 de novembro de 1833. Ibidem. 
testemunhas, agora de marinheiros que trabalhavam no aparelho do Feliz Independente, dos quais se dizia que recebiam altos salários para, mais ràpidamente, aprontá-lo, a fim de deixar o pôrto de Pàranaguá, o quanto antes (16).

Eles também nada viram e nada sabiam. O Promotor Público e - Juiz de Paz dizem que só encontram ditos vagos sôbre o desembarque e que sòmente o Juiz de Guaraqueçaba afirmara que os africanos foram vistos passando em canoas de voga. Nada, porém, em forma legal que pudesse autorizar o prosseguimento do Processo (17).

A Câmara Municipal, convencida de que haviam sido realizadas tôdas as diligências, e que não se chegara a nenhum verdadeiro conhecimento, testemunha o esfôrço do Juiz de Paz, e comunica ao Presidente da Província que nada pôde ser coligido de verdade, e se supunha que, se desembarcados, os africanos haviam tomado outra direção que não a do têrmo de Paranaguá, com destino a Curitiba (18).

A Presidência da Província continua a recomendar a tôdas as Câmaras Municipais o maior empenho e cuidado, no sentido de descobrir-se os africanos que por ventura hajam sido introduzidos ilìcitamente (19).

No ano seguinte, Ezequiel Antônio, morador na ilha do Mel, compareceu ante o Juiz de Paz de Paranaguá, a fim de relatar que, nas proximidades do morro das Conchas, naquela ilha, estivera fundeado um patacho e ouvira dizer a várias pessoas, que o mesmo havia desembarcado negros africanos (20).

Aberto o sumário de inquirição das possíveis testemunhas, o Juiz de Paz nada pôde coligir que fizesse prova, além de vagos rumôres que os escravos haviam passado em direção a Antonina e Morretes. O Comandante da Fortaleza da ilha do Mel, porém, por ofício, comunica ao Juiz de Paz que nos últimos dias de janeiro vira uma embarcação aproximando-se do morro das Conchas, e que ela tentava

(16). - Inquirição ordenada pela Câmara Municipal de Paranaguá, em 2 de janeiro de 1834. D.A.E S $P$. Ofícios diversos - Paranaguá, caixa $n^{\circ} 341$.

(17) . - Ofícios do Promotor Público e do Juiz de Paz, à Câmara Municipal de Paranaguá, de 2 e 8 te janeiro de 1834, respectivamente. Ibidem.

(18). - Ofício da Câmara Municipal de Paranaguá ao Presidente da Província, de 18 de janeiro de 1834 .

(19). - Ofícios do Presidente da Província, às Câmaras Municipais, èm agôsto de 1834. Boletim do A.M. C., v. 47 p. 4.

(20) . - Denúncia de Fzcquiel Antonio ao Juiz de Paz de Paranaguá, em 3 de janeiro de 18:5. D.A.E.S.P. Ofícios diversos - Paranaguá, caixa $n^{\circ} 342$. 
o desembarque sôbre a Vila, de pessoas africanas (21). A distância, contudo, dificultava-lhe a ação.

Informada a Presidência da Província, esta exige nôvo sumário, o que foi realizado. Entretanto, o Juiz de Paz reafirma que nada pôde coligir. As testemunhas ouvidas, alegaram tôdas ignorância acêrca do desembarque ou afirmaram que também só de rumores tinham ciência. O próprio comandante da Fortaleza diz que nada vira, pois que a distância não lhe permitia ver com precisão, mas continuaria atento (22).

Assim, embora as denúncias, e o manifestado interêsse das autoridades provinciais, nada pôde conduzir àquêles que, no litoral do Paraná, realizavam a introdução de escravos novos. Alguns anos depois, em 1848, o Inspetor da Alfândega de Paranaguá, porém, testemunha que o tráfico africano, naquela cidade, havia aumentado de maneira espantosa. E, para o escândalo de todos, o primeiro e único desmoralizado negociador de africanos, em Paranaguá, era o próprio Delegado de Polícia, a quem denuncia ao Inspetor da Tesouraria Geral da Província (23).

Era o Delegado um dos mais fortes comerciantes da praça, proprietário de várias embarcações e consignatário de muitas outras.

Afirma o Inspetor da Alfândega que, desde novembro de 1848 a janeiro de 1849, entraram consignadas àquela autoridade, a barca americana Luisa, os brigues brasileiros Sereia e Desiengano, e a barca à vapor Providência, implicadas no tráfico de escravos ou a êle relacionadas (24).

Desde algum tempo, aliás, o Govêrno norte-americano era alertado para o fato indiscutível de que o tráfico de escravos novos para - Brasil estava sendo conduzido em embarcações de construção e armação americana, mesmo sob a bandeira americana (25).

(21). - Ofício do Commndante da Fortaleza ao Presidente da Província, de 22 de fevereiro de 1835. Ibidem.

(22). - Of:cio do Comandante da Fortaleza ao Presidente da Província, de 23 de abril de 1835 . Ibidem

(23). - Denúncias do Inspetor da Alfândega de Paranaguá, ao Inspetor da Tesouraria Geral da Província, de 14 de agôsto de 1848 e 10 de janeiro de 1849. D. A. E. S. P. Ofícios diversos - Paranaguá. Caixa $n^{\circ} 347$.

(24). - Ibidem.

(25). - Du Ministro Proffitt ao seu Govêrno, em 27 de fevereiro de 1844. In: Despatches, XII. 
A galera Joaquina Guimarães entrara arribada e com utensílios próprios ao tráfico. O brigue Sereia, também arribado, entrava sòmente com pipas e tonéis de água. A carga e o roteiro da barca Luisa, para o Rio da Prata, Bombaim e Zanzibar, eram fictícios. O brigue Sereia estava justamente armando no pôrto sob o pretexto de sair para Bombaim. Aliás, nos anos de 1849 e 1850 aparecem registradas no pôrto de Paranaguá inúmeras entradas e saídas para a costa da África. Tôdas estas ocorrências confirmavam a participação dessas embarcações no tráfico negreiro.

E o Delegado, prevalecendo-se das suas funções e do seu cargo, no desêjo de maior liberdade de ação para os seus negócios escusos, procurava embaraçar a fiscalização aduaneira, por todos os modos, inclusive mandando prender para recrutar, o guarda mais antigo $\mathrm{e}$ de maior confiança da Alfândega (26). A outros movia perseguições, a fim de vingar-se do zêlo que empenhavam na fiscalização.

O Inspetor da Tesouraria Geral da Província informa ao Presidente, as denúncias do Inspetor da Alfândega contra o Delegado, a fim de que sejam tomadas as providências cabíveis, e a Presidência, por Portarias de 27 de janeiro e de $1^{9}$ de fevereiro, exige explicações ao Delegado, acêrca das acusações que the são dirigidas de introdutor de escravos novos e de embaraço à ação fiscalizadora da Alfândega (27).

Antes dessas medidas chegarem a Paranaguá, nôvo incidente se registra entre o Inspetor da Alfândega e o Delegado de Polícia. A 30 de janeiro, entra na barra, a corveta de guerra americana Luisa que envia, com um oficial a bordo, um escaler à Alfândega. O referido oficial tem conferência privada com o Inspetor, ao qual entrega um ofício, e retira-se sem passar pelas autoridades policiais. O Delegado exige explicações ao Inspetor e comunica o insólito caso à Presidência da Província, ao mesmo tempo que acusa o Inspetor de ser seu inimigo pessoal e político (28) .

O agente alfandegário, porém, comunica ao Presidente da Província, a razão da visita da embarcação de guerra americana. Desejava o seu comandante que a Alfândega de Paranaguá retivesse no

(26). - Ofício do inşretor da Alfândega de Paranaguá, à Tesouraria Geral da Provincia, de 8 de janeiro de 1849. D. A. E. S. P. Ofícios diversos - Paranaguá. Caixa $\mathrm{n}^{\circ} 347$.

(27). - Ofício do Inspetor Geral ao Presidente da Província, de 30 de janeiro de 1849. Ibidem.

(28). - Ofício do Delegado de Polícia de Paranaguá, de 2 de fevereiro de 1849, ao Presiderite da Província. Ibidem. 
pôrto a galera Joaquina Guimarães, por julgar que a sua venda, a comerciantes de Paranaguá, fôra fictícia e porque estava a galera americana imp'icada no tráfico de escravos (29). O Inspetor responde ao americano, não ter competência para tanto, mas que retardará o despacho da embarcação até que se pronunciem as autoridades provinciais e do Império. Ora, ñ̃o pudera dar ao Delegado de Polícia, o teor exato das providências solicitadas, pelo americano, por ser êle justamente o nôvo proprietário in nomine da embarcação contestada.

O Delegado responde, a 19 de fevereiro, as acusações, segundo determinara o Presidente. Atribui as denúncias formuladas ùnicamente às desavenças políticas e inimizade pessoal do Inspetor. Contra a acusação de perseguidor dos empregados da Alfândega, diz que se trata de pura calúnia, e argumenta sôbre o tráfico que, se êle já existia, como o afirma o Inspetor, porque não o denunciara antes e só fazia agora que era êle o Delegado? E que influência poderia ter o Delegado, se não era a esta autoridade que cabia tomar as medidas contra os importadores de escravos novos? Se tinha o Inspetor certeza de que aquelas embarcações eram traficantes por que não tomara providências contra as mesmas? E conclui dizendo, ou o Inspetor, movido pela paixão, falta com a verdade, ou prevaricou no exercício de seu cargo (30).

Era. sobretudo, sôbre a oposição política entre saquaremas e luzias (31), que o Delegado pretendia fundar as denúncias do Inspetor, a fim de resguardar-se perante as autoridades provinciais e do Império.

O Inspetor, porém, continua na sua ação comprovadora de que a Polícia de Paranaguá era conivente com o tráfico, se não respon-

(29). - Of́cio do Inspetor da Alfândega de Paranaguá ao Presidente da Provín -ia, de 3 de fevereiro de 1\%49. Ibidem.

(30) . - Resposta do D legado de Polícia de Paranaguá às Porta ias de 27 de janeiro e $1^{\circ}$ de fevereiro, dida em 19 de fevereiro de 1849. Diz, textualmente, ainda: "Sei aquilıtar b:lamente a imoralidade de um tal comércio, quanto êle ofende aos princípios da humanidade e religião, e quanto é oposto às luzes do século em que vivemos; conheço de sobra que a escravatura no país é um mal, é uma calamidade de que por longo trmpo sentirá êle os efeitos. Vejo o perigo iminente em qce se acham muitas localidades do Império, em que a segurança individual só tem por base a inteligência sôbre a ignorância, acompanhado do horror e da fôrça, por conseguinte s:ndo êstes meus princípios e as idéias que tenho bebido pela pequena experiência que o estudo das cousas me tem dado, sem dúvida partilho o desgôsto daquêles que sentem haver ainda no país quem se empregue no comé cio de africanos...". Ibidem.

(31). - Denominação prla qual eram conhecidos, no Paraná, conservadores e liberais. 
sável pelo mesmo. Reiteradas vêzes solicita à Delegacia de Po'ícia, as relações de escravos entrados e saídos do Município, as quais, por lei, deveriam quinzenalmente ser encaminhadas à repartição fiscal . Cientificado o Presidente da Província. em junho de 1849, êle ordena o cumprimento da exigência legal (32). Mas, o Inspetor da Alfândega, logo se veria coagido e impedido mesmo de exercer as suas funções em Paranaguá.

Em 12 de julho, o porteiro da Alfândega, suspenso por um mês, do seu cargo, denuncia junto ao Juiz Municipal, o Inspetor da Alfândega, como conivente com o contrabando de erva-mate, e por injúrias pessoais $(33)$.

O porteiro teria tentado impedir o embarque de uma partida de erva-mate contrabandeada pela Casa de Isaias d'Elia, no que fôra contrariado pelo Inspetor que, além de insultá-lo, permitira o referido embarque e o suspendera de seu cargo, ações estas motivadas pelo espírito de partido, antagonismo político e vingança contra aquêles que o contrariavam.

O Juiz Municipal estreitamente ligado aos inimigos políticos do Inspetor e acusado também de conivência com o tráfico de escravos, condena e decreta a prisão daquêle, por seis meses. Sob coação e impedido do exercício do seu cargo, o Inspetor deixa Paranaguá, a fim de procurar apôio de autoridades da Côrte (34).

Assumindo a Inspetoria, o Escrivão da Alfândega, logo depois nela confirmado, encontraria os mesmos problemas e evidências do tráfico negreiro no litoral de Paranaguá. Assim, já em março de 1850, comunicava ao Presidente da Província, as suas suspeitas acêrca de várias embarcações que eram consignadas a comerciante notòriamente conhecido como traficante. Em 28 de fevereiro, entrara no pôrto o bergantim brasileiro Dona Ana, por arribação. Convencido que o bergantim saíra de portos estrangeiros com carga, e que a descarregara no litoral da Província, multou-a e solicitou ao Juiz Municipal a abertura de inquérito. Essa embarcação havia entrado em Paranaguá, a 3 de agôsto, com o nome de Leônidas, e saíra para Ba-

(32). - Ofícios do Inspetor da Alfândega ao Delegado de Polícia em 14 de março, e em 11 de abril de 1849. Ofício do mesmo Inspetor ao P:esidente da Província, em 2 de maio. Resposta do Delegado de Polícia ao Presidente da Província, em 12 de junho de 1849. Ibidem.

(33). -- Denúncia do porteiro da Alfândega, Quintino Cardoso dos Santos, ao Juiz Municipal, em 12 de julho de 1849. Ibidem.

(34). - Comunicação do Escrivão da Alfândega ao Presidente da Província, de 31 de julho de 1849. Ibidem. 
távia, em 6 de setembro. Logo depois, também sem carga, entrara arribada em 28 de outubro, para novamente sair para Batávia, a 19 de dezembro. Era pois, em pouco tempo, a segunda entrada por arribaç̃̃o simulada que realizava (35).

Pouco depois, em 23 de março, entrava também por arribação simulada, o bergantim nacional Screia que partira com destino a Havana.

Portarias repetidas da Presidência da Província, insistem junto as autoridades municipais sôbre as contínuas denúncias e a necessidade de encontrar-se o responsável ou os responsáveis pela introdução de escravos novos. O Delegado, o Sub-Delegado de Polícia, o Juiz Municipal, todos negam que tenha havido desembarque de negros e, sobretudo, a existência, na cidade, de depósitos para a sua recepção (36) . O Sub-Delegado, aliás, afirmava que as denúncias eram o fruto do desêjo de abalar a reputação dos comerciantes de Paranaguá (37).

Este comum acôrdo das autoridades locais culminaram na sentença dada pelo Juiz Municipal no auto sumário de inquirição referente ao bergantim Dona Ana, embora tudo, no Processc, levasse a outras conclusões. O Inspetor da Alfândega, qualificado de denunciante, foi obrigado ao pagamento das custas do Processo (38).

O Inspetor, no entanto, comunica ao Presidente da Província, a parcialidade do Juiz Municipal no caso flagrante do bergantim Dona Ana. Ouvido o Procurador Fiscal da Província, êste emite parecer no sentido de que o Promotor Público da Comarca, mova ação anulatória da sentença (39), o que foi, aliás, mais tarde realizado.

(35). - Do Inspetor dn Alfândega de Paranaguá ao Presidente da Província, em 7 de março de 1850. D. A. E. S. P. Ofícios diversos - Paranaguá. Caixa $n^{\circ} 348$.

(36). - Portarias da Presidência da Província, de 5 e de 27 de março. Ofícios do Delrgado de Polícia ao Presidente da Província, de 3 de abril, e do Juiz Municipal, de 20 de abril de 1850 . Ibidem.

(37). - Do Sub-Delegaro de Polícia de Paranaguá ao Presidente da Província, em 14 de atril de 1850. Ibidem.

(38). - Ofício do Inspetor da Alfândiga de Paranaguá ao Presidente da Província, de 31 de maio de 1850 . Ibidem.

(39). - Parecer do Procurador Fiscal da Província, de 11 de julho de 1850, mandando anular a sentença do Juiz Municipal de Paranaguá no Processo do brigue Dona Ana. Ibidem. 


\section{3. - O INCIDENTE DO CORMORANT.}

A questão do tráfico negreiro em Paranaguá deveria agravar-se sobremodo, no ano de 1850, com o incidente do Cormorant .

Em 29 de junho, pelas 11 horas, entrou o cruzador inglês no pôrto de Paranaguá. Imediatamente foi ao seu encôntro a visita da Alfândega. O Comandante do Cormorant entrega ao Guarda-Mor da Alfândega, dirigido ao Comandante das Fôrças da cidade, um ofício explicativo da sua presença no pôrto. Logo em seguida escaleres do Cormorant, com homens armados, dirigiram-se aos fundeadores de carga e descarga, ocupando os bergantins Dona Ana e Sereia, e a galera Campeadora, passando-lhes cabos e rebocando-os para junto do cruzador.

O Inspetor da Alfândega manda entregar o ofício ao Delegado da Polícia, que não quís recebê-lo, nem tão pouco o Coronel Chefe da Guarda Nacional, de tal maneira que foi o mesmo depositado no Correio local.

Eram evidentes os propósitos do cruzador, aprisionar embarcações nacionais comprometidas ou suspeitas de comprometimento no tráfico de escravos novos.

O brigue Astro, também surto no pôrto, foi segundo Vieira dos Santos, afundado pelo seu próprio Capitão, evitando de cair nas mãos dos inglêses (40). O Juiz Municipal, em seu relatório das ocorrências, diria não saber por quem fôra o brigue afundado dentro do próprio pôrto e à vista de todos (41).

No próprio dia 30 , ante os propósitos do cruzador, o Juiz Municipal dirige ofício ao seu Comandante, protestando contra o ato inquinado de violador das leis e tratados internacionais (42), o qual, porém, respondeu-lhe estar cumprindo ordens superiores e não ter que dar-lhe contas das mesmas (43). Ordenou o Juiz Municipal ao

(40). - Vieira dos Santos, Antonio. - Memória histórica... de Paranaguá. V. 2, p. $223,229$.

(41). - Ofício do Juiz Municipal de Paranaguá ao Presidente da Província, de 2 de julho de 1850 . D. A. E. S. P. Ofícios diversos - Paranaguá. Caixa $n^{9}$ 348 .

(42). - Ofício do Juiz Municipal de Paranaguá ao Comandante do Cormorant, em 30 de junho de 1850 . Cópia. D. A. E. S. P. Ofícios diversos - Paranaguá. Caixa $n^{\text {? } 348 . ~}$

(43). - Ofício do Comandante do Cormorant ao Juiz Municipal de Paranaguá, em 30 de junho de 1850. Cópia. Ibidem. 
Comandante da Fortaleza que impedisse, inclusive pelas armas, qualquer tentativa de saída do cruzador, com as embarcações nacionais.

Na manhã do dia 1\%, o Commorant, com velocidade e surprêsa, conduzindo aquelas embarcações, saiu rumo à barra. Foi quando, no dizer do Inspetor da Alfândega, registraram-se cênas desagradáveis . Tripulantes daquelas embarcações, capitaneados pelos Comandantes respectivos, desenfreadamente e sem formalidade alguma, invadiram a Fortaleza da Barra, com pretensões de, à fôrça das armas, embaraçar a saída do vapor inglês (44).

O mais inflamado de todos era o Capitão do Astro que providenciou inclusive a aquisição de pótvora. 80 a 100 homens haviam acorrido à Fortaleza. Quando passava o Cormorant, depois de não haver recebido a barca do registro, a Fortaleza abriu fogo que, vivíssimo de parte a parte, durou cêrca de um quarto de hora, não impedindo porém, o avançar do Cormorant. Esste, depois que saiu do alcance da Fortaleza, deu fundo por algum tempo, queimando e metendo a pique os bergantins, levando apenas a galera Campeadora.

O incidente foi logo comunicado e relatado pelas autoridades locais ao Presidente da Província, repercutindo com intensidade, sobretudo na Côrte, onde movimentou a chancelaria imperial e a Câmara dos Deputados (45).

As embarcações apresadas, como esclarece o Inspetor da Alfândega, se encontravam surtas no pôrto, mas não estavam em despacho, pelas suspeitas de contrabando que sôbre elas recaiam. Os brigues Dona Ana e Sereia, com arribadas simuladas, e a galera Campeadora, entrada a 17 de junho, com destino diverso do despacho. Embora cientificadas as autoridades, haja vista o processo do brigue Dona Ana, por proteção aos seus consignatários, ou por qualquer outro motivo particular, deixaram as autoridades responsáveis, notadamente o Juiz Municipal, de conhecer de tais suspeitas do tráfico ilícito, gerador do incidente (46).

As informações de Hudson a Palmerston, além de atribuir ao Juiz Municipal tôda a instigação do ataque ao Cormorant, rebelan-

(44). - Relatório do Inspetor da Alfândega de Paranaguá ao Presidente da Província, em 2 de julho de 1850. Ibidem.

(45). - A Côrte, aliás. já se encontrava tomada pela questão da repressão ao tráfico, com a interpelação inclusive do Ministro dos Estrangeiros que devia comparecer perante a Câmaı a dos Deputados.

(46). - Relatório do Inspetor da Alfândega de Paranaguá ao Presidente da Província, de 2 de julho de 1850. 
do-se contra um ato de acôrdo com as convenções existentes entre o Brasil e a Grã-Bretanha, para a suspensão do tráfico de escravos, o apontam como magistrado corrupto que permitiu, sob a sua imediata proteção, fôsse o pôrto de Paranaguá transformado em pôrto negreiro, onde se aprestavam, equipavam, armavam e encontravam ancoradouro especial, as embarcações traficantes (47).

Enquanto na Câmara dos Deputados, discutia-se o projeto de lei que deveria extinguir o tráfico, a Presidência da Província com enérgica Portaria mandava reprimir qualquer tentativa de desembarque, no litoral paranaense. O Sub-Delegado de Paranaguá continuava na sua parte de que não existia tráfico negreiro na sua jurisdição (48).

Poucos dias depois do incidente do Cormorant, o brigue Astro, afundado na ocasião, foi posto a flutuar. Portaria do Presidente da Província, ordena que se proceda ao seu exame. Já estava o brigue com despacho, devendo sair com destino às ilhas Canárias, quando o Inspetor procede a sua vistoria. O exame constata claramente que a embarcação empregava-se no tráfico ilícito de africanos: mantimentos, água doce, caldeiras e, sobretudo, a presença do baileo, atestavam a sua utilização.

O seu consignatário era um súdito português, sócio em casa de negócio com o antigo Delegado, comerciante várias vêzes apontado como o prircipal introdutor de escravos novos. Na opinião pública, e na do Inspetor da Alfândega, êste era o seu verdadeiro consignatário. Encontrara, aliás, durante a vistoria, entre os papéis do brigue, documento do próprio punho e assinado por êle, comprovando a sua posição (49).

Terminado o exame, e com receio que a embarcação se evadisse, impossibilitanto os trâmites legais, o Inspetor avisa a Fortaleza, no sentido de que impeça qualquer tentativa de saída. E, de fato, ela se fêz, mas, embora o fogo da Fortaleza, o Astro conseguiu evadir-se. E, como relata o Inspetor ao Presidente da Província, fogos de artifício foram espocados comemorando a vitória dos traficantes sôbre o agente fiscal (50). A ordem da Presidência da Província não atingia apenas o Astro. Assim, o Inspetor da Alfândega procedeu também a

(47). - Da correspondência de Hudson a Palmerston, de 27 de julho de 1850.

(48). - Portaria da Presidência da Província, de 9 de julho de 1850. Ofício do Sub-Delegado ao Piesidente da Província, de 3 de agôsto de 1850. D.A.E.S.P. Ofícios diversos - Paranagua. Caixa $n^{\circ} 348$.

(49). - Relatório do Inspetor da Alfândega ao Presidente da Provincia, de 22 de agôsto de 1950. Ibidem.

(50). - Ibidem. 
vistoria de embarcadouros da ilha da Cotinga, onde existiriam depósitos para recepç乞̃o dos negros. Ali também encontrou pipas, tonéis, barris, toneletes, ca'deiras, escotilhas de madeira, no pôrto da chácara de outro conhecido comerciante, irmão do antigo Delegado (51) .

Entretanto, dias depois, os delegados de Paranaguá diziam ao Presidente da. Província que era ridícula qualquer assertiva no sentido de que a ilha da Cotinga, à vista da cidade, pudesse abrigar tais estabelecimentos $(52)$.

Os rumôres, as denúncias, continuaram ainda por algum tempo (53). Novas suspeitas levam ao exame, em julho de 1851, do patacho português Amélia, entrado do Rio da Prata. Nada, porém, foi encontrado pelo Inspetor da Alfândega que, no entanto, afirma haver procedido a vistoria por tratar-se de uma embarcação portuguêsa, bandeira que havia acobertado muitas vêzes o tráfico negreiro em Paranaguá (54).

A animosidade entre os comerciantes acusados do tráfico e o agente alfandegário, cria ainda problemas para êste. Queixas sôbre a sua atuação são apresentadas ao Presidente da Província, e tôdas êle as atribui ao rigor que empenhara para reprimir o tráfico, o que, aliás, vinha conseguindo (55).

Ainda em 1853, José Lourenço de Sá Ribas, promotor público de Curitiba, ante novas denúncias de tráfico negreiro no litoral do $\mathrm{Pa}$ raná, declara não acreditar que o mesmo prossiga, porém, atendendo ao anterior comportamento de certas autoridades de Paranaguá, propunha que as mesmas fôssem destituídas, porque eram justamente aquelas que outrora haviam protegido êsse tráfico, e que algumas, embora novas, estavam debaixo da imediata influência daquêle de quem francamente se dizia ser o autor do crime (56).

A vigilância, aliás, exigida ainda pelas autoridades provinciais paulistas surtia efeito. O Inspetor da Alfândega devia mensalmente

(51). - Ibidem.

(52). - Of́́cio do Delegado de Polícia, de 3 de setembro de 1850. Ibidem.

(53). - Ver: Canabrava, Um desembarque clandestino de escravos em Cananéia. In: "Revista de História", São Paulo, n⿳ 4: 559-62, out.-dez., 1950.

(54). - Ofício do Inspetor da Alfândega ao Presidente da Província, de 30 de julho de 1851. D. A. E. S. P. Ofícios diver sos - Paranaguá. Caixa n $^{0} 348$.

(55). - Resposta do Inspetor da Alfândega de Paranaguá à Portaria de 13 de novembro de 1853, da Presidência da Província. D. A. E. S. P. Ofícios diversos - Paranaguá. Caixa $n^{\circ} 349$.

(56). - Ofírio do Promotor Público de Curitiba, José Lourenço de Sá Ribas, ao Presidente da Província, de 24 de fevereiro de 1853. D. A. E. S. P. Ofícios diversos - Paranaguá. Caiva $\mathrm{n}^{\circ} 211$. 
informar se as próprias autoridades policiais e judiciárias de Paranaguá, cumpriam com os seus deveres, e, em abril de 1853, dizia que após o processo do brigue Astro, não tinha havido no pôrto paranaense, preparo de navios para a costa da África e nem a introdução de africanos boçais (57). Assim, em maio, o Promotor também informava a inexistência de novidades, e que nada de suspeito ocorria. Estariam as autoridades de Paranaguá cumprindo agora, com exatidão, os seus deveres (58).

A instalação da Província do Paraná, no final de 1853 , e a presença em Curitiba das autoridades provinciais, a começar pelo Presidente Zacarias de Goes e Vasconcellos, iriam dificultar a introdução de escravos novos na costa paranaense. Contudo, oposições políticas levavam Zacarias, de maneira aberta a referir-se ao chefe do Partido Conservador em Paranaguá, como contrabandista, pela sua notória participação no tráfico ilícito (59), ao mesmo tempo que agia politicamente no sentido de libertar o Paraná do que êle chamava, a nefasta influência do Astro Paranaense, aludindo ao barco negreiro ao qual aquêle político estava ligado.

Os boatos, entretanto, continuavam a respeito da atividade negreira no litoral paranaense. Ainda, em maio de 1855, teria naufragado no Superaguí, uma embarcação suspeita de empregar-se no tráfico de africanos. Diligências efetuadas pelo Inspełor da Alfândega e pelo Delegado Suplente, não encontraram vestígios do referido naufrágio (60). Por sua vez, o Capitão do Pôrto de Paranaguá, nó entanto, denunciava às autoridades provinciais, o vapor Paraense, que fazia a linha regular entre o Rio de Janeiro e Santa Catarina, de não se prestar às formalidades legais, como a visita da Fortaleza, o que resultava em abusos e na faculdade inaudita de traficar impunemente com africanos boçais $(61)$.

À Presidência da Província continuavam a chegar denúncias acêrca do desembarque clandestino de africanos. Em julho de 1856, o próprio Chefe de Polícia desce ao litoral, a fim de proceder diligências

(57). - Informação do Inspetor da Alfândega, de 24 de abril de 1853. Ibidem.

(58). - Ofício do Prcmotor José Lourenço de Sá Ribas, ao Presidente da Província, de $1^{\circ}$ de maio de 1953. Ibidem.

(59). - Cartas de Zacarias de Goes e Vasconcellos a Jesuíno Marcondes, de 11 de outubro de 1855 e de $1^{\circ}$ de novembro de 1856 . B. P. P.

(60). - Cópias de ofícios do Inspetor Francisco Gonçalves de Araújo e do Delegado Joaquim Feliz da Silva, encaminhadas pelo Chefe de Polícia da Província, em 4 de abril de 1855 . D. A. E. S. P. Ofícios diversos - 1855.

(61). - Ofício do Capitâo Victor S. Tiago Subrá ao Presidente da Província, de 30 de maio de 1855 . D. A. E. S. P. Ofícios diversos -1855 . 
sôbre o possível desembarque de negros no litoral de Guaratuba. A Câmara Municipal desta Vila informava não ter ocorrido o desembarque, tal a vigilância empregada (62). O Chefe de Polícia, examinando a costa, na extensão de 12 léguas, não constata nenhum indício positivo. Ninguém sabia da chegada dos africanos e era impossível dar imediato consumo aos 180 escravos que teriam sido desembarcados, airda mais considerando-se que, pelas últimas estatísticas, o Município não teria 200 escravos. Testemunhas ouvidas, moradores de Guaratuba, inclusive o próprio pároco, todos negaram a possibilidade do desembarque. Alguns referem que, em anos anteriores, teria havido desembarque em São Francisco e que os negros passavam para o $\mathbf{P a}$ raná, mas que desde a elevação da Comarca à Província, tal não mais ocorrera (63).

\section{$*$ \\ 4. - CONCLUSÃO.}

Do exposto, conclui-se que, após a proibição do tráfico em 1831, registra-se comprovada atividade negreira no litoral paranaense, com a participação inclusive de autoridades de Paranaguá que, assim, facilitavam a entrada de escravos novos.

Essa atividade culminou com o grave incidente do Cormcrant, em 1850 , o qual levou à maior cuidado das autoridades do Império e provinciais, em relação ao litoral de Paranaguá, declinando, por isso mesmo, as evidências do tráfico, mas cujos̀ rumôres continuaram ainda por tôda a década.

(62). - Ofício do Presidente da Câmara Municipal de Guaratuba, ao Presidente da Província, de 19 de julho de 1856. D. A. P. E. P. Ofícios diversos 1856.

(63). - Inquérito sôbre o desembarque de negros, encaminhado pelo Chefe de Polícia, José Antônio Vaz de Carvalhaes, ao Presidente da Província. D.A.P.E.P. Ofícios diversos - 1956. 